${ }^{6}$ Reading AE, Cox DN. The measurement of pain. In: Oborne DJ, ed. Research in psychology and medicine. Vol 1. London: Academic Press, 1979:33.

${ }^{7}$ Alberman E. Facts and figures. In: Chard T, Richards M, eds. Benefits and hazards of the new obstetrics. London: Heinemann Medical Books, 1977 :

${ }^{8}$ Gruber CM Jr. Codeine and propoxyphene in postepisiotomy pain. A two-dose evaluation. $\mathcal{F} A M A$ 1977;237:2734-5.

${ }^{9}$ Baker S. A survey of postnatal perineal discomfort. London: S Maws and Sons, 1973.

${ }^{10}$ Coats PM, Chan KK, Wilkins M, Beard RJ. A comparison between midline and mediolateral episiotomies. Br f Obstet Gynaecol 1980;87:408-12.
11 Beischer NA. The anatomical and functional results of mediolateral episiotomy. Med f A ust 1967;ii:189-95.

12 Johnson JE. Effects of accurate expectations about sensations on the sensory and distress components of pain. F Pers Soc Psychol 1973;27:261-75.

${ }^{13}$ Reading AE. The short term effects of psychological preparation for surgery. Soc Sci Med [Med Psychol Med Sociol] 1979;13A:641-54.

${ }^{14}$ Cogan R, Henneborn W, Klopfer F. Predictors of pain during prepared childbirth. F Psychosom Res 1976;20:523-33.

${ }^{15}$ Dennerstein L, Wood C, Burrows GD. Sexual response following hysterectomy and oophorectomy. Obstet Gynecol 1977;49:92-6.

(Accepted 21 October 1981)

\title{
Epidemiology
}

\section{Risks of zoonoses in a veterinary service}

\author{
P J CONSTABLE, J M HARRINGTON
}

\begin{abstract}
A survey was undertaken among the veterinary staff of the Ministry of Agriculture, Fisheries, and Food and the Institute for Research in Animal Diseases to estimate the distribution of occupationally acquired zoonoses in this population. A self-administered questionnaire was distributed to 1717 staff, $1625(95 \%)$ of whom responded. It was observed that both laboratory and technical support staff were at risk from a variety of zoonotic infections, though generally to a lesser extent than veterinary surgeons. A history of injury while handling animals was reported frequently by veterinarians $(45 \%)$. Accidental self-injection with vaccines was also commonly reported. It is suggested that both injury from animals and accidental self-injection are associated with the risk of zoonotic infection.
\end{abstract}

\section{Introduction}

Field and laboratory veterinary work has long been associated with a wide variety of hazards including glanders ${ }^{1}$ and brucellosis. ${ }^{2}$ It is only in the past few years, however, that attention has been directed to the wider occupational health problems of such workers.

During the past decade considerable attention has been paid to the occupational hazards of laboratory workers and particularly to their risk of contracting laboratory-acquired infection. ${ }^{3-5}$ The veterinarian and the scientist in the Government Veterinary Service are both exposed to the hazards of zoonotic infection.

Civil Service Medical Advisory Service, London SW1H 9EU P J CONSTABLE, MD, MRCGP, principal medical officer

\footnotetext{
Institute of Occupational Health, Birmingham University, Birmingham

J M HARRINGTON, MD, MRCP, professor
}

The field staff of the Agricultural Development and Advisory Service, supported by veterinary and scientific staff of the Central Veterinary Laboratory and the veterinary investigation centres, play the principal part in controlling scheduled diseases among farm animals. These laboratories provide a diagnostic service as well as conducting research relevant to the ministry's animal disease control programme, while further basic research on animal disease is carried out by establishments in the Agricultural Research Council.

A survey of this group would have two objectives: firstly, to obtain an estimate of the prevalence of the zoonotic infections in this population and, secondly, to aid in planning the deployment of occupational health resources to the veterinary services.

\section{Population and methods}

Three main types of work are performed. Veterinary surgeons form one coherent group with a common exposure to animals and animal products in their profession and training. A second group consists of the supporting technical and experimental staff employed on experimental farms, and in veterinary investigation centres and other units. Members of this group also have close contacts with animals and animal products but probably less so than professional veterinarians. The third category consists of the various grades of scientific staff whose working environment is generally the laboratory.

Information was sought by questionnaire on any personal history of zoonotic infection, injury either by animals or in the laboratory, and accidental self-administration of drugs and vaccines intended for animal use. The study population consisted of Ministry of Agriculture, Fisheries, and Food veterinary and support staff in England, Wales, and Scotland, together with similar groups of staff from the Agricultural Research Council's Institute for Research in Animal Disease. The administrative roll was used to delineate the study population and exclude those staff absent on prolonged study leave or on lengthy overseas visits.

After a pilot study of the use of the questionnaire on a small sample of the study population, a total of 1717 questionnaires were distributed resulting in a $94.7 \%$ (1625) response rate, comprising 563 professional veterinary surgeons, 690 scientific staff, and 372 technical support staff. A follow-up study of $10 \%$ of the non-responders did not suggest that this was a major source of bias.

The information from the questionnaire was coded and recorded on punch cards for subsequent analysis by computer using the statistical package for social sciences. 


\section{Results}

The age and sex distribution of the laboratory and technical staff was broadly similar. Whereas both sexes were evenly distributed in these two groups, only $10 \%$ of the professional veterinary staff were women. The age distribution of the veterinary group differed in that its mode occurred in the 50-54 year age group, some 15 to 20 years older than that observed in the age distribution of the other groups.

The laboratory and technical groups had shorter duration of employment in veterinary work than professional veterinarians.

\section{ZOONOSES}

Table I shows the distribution of zoonotic infections in the study population. The overall incidence rates of the common zoonoses such as animal ringworm, brucellosis, and Newcastle disease are higher in the veterinary and technical support staff than in laboratory workers. In contrast, ornithosis, salmonellosis, and $Q$ fever occurred at least as often among laboratory staff.

TABLE $\mathrm{I}-$ Disease rates per 100000 person/years in veterinary work. (Total cases: No of cases while employed in government service in parentheses)

\begin{tabular}{|c|c|c|c|c|}
\hline Disease & $\begin{array}{c}\text { Total } \\
(\mathrm{n}=23415)\end{array}$ & $\begin{array}{l}\text { Veterinary } \\
(n=13053)\end{array}$ & $\begin{array}{l}\text { Scientific/ } \\
\text { laboratory } \\
(\mathrm{n}=6657)\end{array}$ & $\begin{array}{c}\text { Technical/ } \\
\text { support } \\
(\mathrm{n}=3702)\end{array}$ \\
\hline Animal ringworm & $1222(280: 116)$ & $1739(227: 61)$ & $390(26: 25)$ & $891(33: 30)$ \\
\hline Anthrax & $26(6: 1)$ & $38(5: 1)$ & $15(1: 0)$ & \\
\hline Brucellosis & $795(186: 81)$ & $1187(115: 51)$ & $255(17: 17)$ & $378(14: 13)$ \\
\hline $\begin{array}{l}\text { Erysipeloid } \\
\text { Weil's dicease }\end{array}$ & $43(10: 5)$ & $77(10: 5)$ & & \\
\hline $\begin{array}{l}\text { Weil's disease } \\
\text { Other leptospiral }\end{array}$ & $4(1: 0)$ & $8(1: 0)$ & & \\
\hline $\begin{array}{l}\text { Other leptospiral } \\
\text { infections }\end{array}$ & $13(3: 2)$ & $23(3: 2)$ & & \\
\hline Newcastle disease & $346(81: 79)$ & $483(63: 61)$ & $75(5: 5)$ & $351(13: 13)$ \\
\hline Ornithosis & $9(2: 1)$ & $8(1: 1)$ & $15(1: 0)$ & \\
\hline Orf-paravaccinia & $98(23: 12)$ & $138(18: 8)$ & $45(3: 3)$ & $54(2: 1)$ \\
\hline $\begin{array}{l}Q \text { fever } \\
\text { Salmonellosis }\end{array}$ & $34(8: 8)$ & $23(3: 3)$ & & $01(2,2)$ \\
\hline $\begin{array}{l}\text { Salmonellosis } \\
\text { Streptococcus suis }\end{array}$ & $111(26: 23)$ & $92(12: 9)$ & $165(11: 11)$ & $81(3: 3)$ \\
\hline $\begin{array}{l}\text { infection } \\
\text { Tuberculosis }\end{array}$ & $\begin{array}{c}9(2: 2) \\
60(14: 6)\end{array}$ & $84(11: 3)$ & $\begin{array}{l}15(1: 1) \\
45(3: 3)\end{array}$ & $27(1: 1)$ \\
\hline
\end{tabular}

Fourteen people reported that they had developed tuberculosis during their employment, only one of which was due to Mycobacterium bovis. A laboratory worker developed pulmonary tuberculosis while working with $M$ tuberculosis.

\section{NUMBERS OF INFECTIONS REPORTED BY STUDY POPULATION}

Respondents were asked to record the number of different zoonotic infections that they had experienced, but recurrences and relapses of earlier infections were not included (table II).

TABLE II-Zoonotic infections reported among occupational groups

\begin{tabular}{|c|c|c|c|c|c|c|c|}
\hline \multirow{2}{*}{$\begin{array}{l}\text { No of } \\
\text { reported } \\
\text { episodes of } \\
\text { zoonoses }\end{array}$} & \multicolumn{2}{|c|}{ Veterinarians } & \multicolumn{2}{|c|}{ Scientific staff } & \multicolumn{2}{|c|}{$\begin{array}{l}\text { Technical/ } \\
\text { support staff }\end{array}$} & \multirow{2}{*}{ Total } \\
\hline & No & $\begin{array}{l}\% \text { of } \\
\text { grade }\end{array}$ & No & $\begin{array}{l}\% \text { of } \\
\text { grade }\end{array}$ & No & $\begin{array}{l}\% \text { of } \\
\text { grade }\end{array}$ & \\
\hline $\begin{array}{l}0 \\
1 \\
2 \\
3\end{array}$ & $\begin{array}{r}200 \\
172 \\
121 \\
70\end{array}$ & $\begin{array}{l}35 \cdot 5 \\
30 \cdot 6 \\
21 \cdot 5 \\
12 \cdot 4\end{array}$ & $\begin{array}{r}607 \\
66 \\
10 \\
7\end{array}$ & $\begin{array}{r}88 \cdot 0 \\
9 \cdot 6 \\
1 \cdot 4 \\
1 \cdot 0\end{array}$ & $\begin{array}{r}250 \\
97 \\
19 \\
6\end{array}$ & $\begin{array}{r}67 \cdot 2 \\
26 \cdot 1 \\
5 \cdot 1 \\
1 \cdot 6\end{array}$ & $\begin{array}{r}1057 \\
335 \\
150 \\
83\end{array}$ \\
\hline Total & 563 & $100 \%$ & 690 & $100 \%$ & 372 & $100 \%$ & 1625 \\
\hline
\end{tabular}

\section{ACCIDENTS AT WORK}

Consideration of accidents at work is commonly limited to a review of the injuries sustained and the time lost from employment. In veterinary work an added factor is the risk of contracting a zoonosis either from handling infected material in the laboratory or a sick animal in the field. Table III shows the distribution of those reporting such injuries from laboratory accidents or handling animals at some time during their employment.
TABLE III-Injuries resulting from accidents at work

\begin{tabular}{lrrrllc}
\hline & \multicolumn{2}{c}{$\begin{array}{c}\text { Laboratory } \\
\text { accident }\end{array}$} & & \multicolumn{2}{c}{$\begin{array}{c}\text { Animal handling } \\
\text { accident }\end{array}$} \\
\cline { 2 - 3 } \cline { 6 - 7 } & \multicolumn{1}{c}{ No } & $\%$ & & No & $\%$ \\
\hline Veterinarians $(n=563)$ & 44 & $7 \cdot 8$ & & 397 & $70 \cdot 7$ \\
Laboratory staff $(\mathrm{n}=690)$ & 226 & $32 \cdot 9$ & & 103 & $14 \cdot 9$ \\
Technical staff $(\mathrm{n}=355)$ & 19 & $5 \cdot 4$ & & 179 & $42 \cdot 1$ \\
\hline
\end{tabular}

\section{Discussion}

Though the hazards to veterinary workers from specific zoonoses have been extensively documented, few studies have given any measure of the risk entailed. In this survey prevalence rates could not be derived from the data because of the varying periods of employment to the study population. Calculation of the number of episodes of infection per 100000 man years at risk allows comparison among populations but provides a poor estimate of the incidence of disease, masking any change in the level of risk that may have occurred during the working life of the study population.

Two recent surveys of veterinarians have attempted to quantify these risks. Robinson and $M_{\text {etcalfe }}{ }^{6}$ used a crosssectional design among veterinary surgeons attending a conference in New Zealand, while Schnurrenberger $e t a l^{78}$ followed up a cohort of veterinarians registered in Illinois.

The results of this survey highlight two problems-firstly, the risks of this occupational group to some specific zoonoses and, secondly, a suggested association between accidental injury and zoonotic infection.

Animal ringworm was the commonest reported zoonoses with an overall prevalence of $24 \%$. Veterinary surgeons regarded the infection as little more than a minor nuisance, usually contracted early in their careers and seldom recurring. Studies in other occupational groups are sparse, ${ }^{910}$ and data are lacking with which to make an accurate comparison.

In an analysis of anthrax notification from 1968 to $1977^{11}$ no cases were recorded among veterinary workers. Those recorded here all occurred before 1961. Good working practice on the investigation of sudden death in cattle contributes to the protection of the veterinary workers. Although the number of anthrax isolates is increasing, primarily from contaminated bonemeal, notification of this disease in the United Kingdom is falling.

Until now brucellosis has caused the greatest morbidity in this occupational group. For several years the serological testing of cattle for brucellosis has been concentrated at two centres where automated equipment reduces the exposure of the laboratory staff, who themselves are regularly examined at intervals for antibodies to Brucella abortus. Although seroconversion occurs in exposed staff, it is rarely accompanied by clinical features of the disease. Comparison with the rate of infection in the general population is hampered because brucellosis is not a notifiable disease. Some indication is given by several population surveys reported during the past 20 years. ${ }^{212} 13$ Of the 419 cases of brucellosis reported to the Communicable Disease Centre of the Public Health Laboratory Service between 1975 and 1979, 227 were in farm workers. Veterinarians ( 37 cases) form the next most susceptible group. Until 1979 veterinary surgeons were not only at risk from the diseased animal but also from exposure to live $B$ abortus strain 19 vaccine, ${ }^{214}{ }^{15}$ the manufacture of which has now ceased with a consequent decline in the hazard.

Coghlan ${ }^{16}$ reported that only one veterinary surgeon contracted leptospirosis during 1958, possibly because of the wider use of protective clothing. In this survey six cases occurred in veterinarians, only one of which was Weil's disease. Studies of other veterinary populations have confirmed a low rate of infection. In New Zealand Robinson and Metcalfe ${ }^{6}$ reported that of 86 veterinary surgeons, only one had a raised antibody titre, although two others gave a history of leptospirosis. In the Illinois survey ${ }^{7}$ a history of leptospirosis was given by $1.8 \%$ of veterinarians with positive serology in $1.2 \%$ of the study 
population. Changes in work patterns after alterations in policy may be reflected in an altered level of risks to staff. The decline in the attack rate of Newcastle disease among veterinarians reflects the reduced level of exposure to the study population after alteration in the method of inspection of poultry houses. In contrast, recently, attention has been focused on Chlamydia $B$ infection in poultry process plants where contact with ducks has proved a source of infection. ${ }^{17}$ Ornithosis presents an occupational hazard to both veterinarians and to veterinary laboratory workers. Of the two cases reported here, one infection was acquired in a laboratory, while the other followed a routine inspection of a poultry station.

The crude prevalence of tuberculous infection among this population of veterinary workers of 60 per 100000 person years at work is higher than the estimated annual notification rate for the general population of 16.4 per $100000,{ }^{18}$ though only half the prevalence observed by Harrington and Shannon ${ }^{3}$ among medical laboratory workers. The figures from the questionnaire may exaggerate the present risk of infection as only four cases occurred between 1960 and 1981 . Within this population; the risk of tuberculosis infection appears to be unevenly distributed, exposure being highest in the units handling tuberculous material intensively.

Both the laboratory and the field veterinary workers are exposed to zoonoses. The risk of zoonotic infection appeared highest in the veterinary surgeon and multiple zoonoses were reported most often among veterinarians. The unpredictability of animal behaviour renders the administration of drugs and vaccines to animals potentially hazardous. The risk of injury from handling animals is common; half the technical staff and two-thirds of the veterinary staff reported such injury some time during their careers; $70 \%$ of these being serious enough to necessitate time off work. Compounding these risks is that of injury when handling animals which may be harbouring a zoonoses.

A comparison between the distribution of zoonoses in those giving a history of injury from an animal or laboratory accident and those without a history of such injury (table IV) suggests, in this population, that there is an association between injury by an animal and history of a zoonotic infection; this association is not shown for laboratory accidents.

TABLE IV-Prevalence of zoonoses in those injured by animal

\begin{tabular}{|c|c|c|c|c|c|c|c|c|c|}
\hline & \multicolumn{9}{|c|}{ Any zoonoses } \\
\hline & \multicolumn{3}{|c|}{ Vets } & \multicolumn{3}{|c|}{ Scientists } & \multicolumn{3}{|c|}{ Technical } \\
\hline & No & Yes & Total & No & Yes & Total & No & Yes & Total \\
\hline $\begin{array}{l}\text { Injured by } \\
\text { animals } \\
\text { No } \\
\text { Yes }\end{array}$ & $\begin{array}{r}83 \\
119\end{array}$ & $\begin{array}{r}83 \\
278\end{array}$ & $\begin{array}{l}166 \\
397\end{array}$ & $\begin{array}{r}530 \\
80\end{array}$ & $\begin{array}{l}57 \\
23\end{array}$ & $\begin{array}{l}387 \\
103\end{array}$ & $\begin{array}{l}132 \\
105\end{array}$ & $\begin{array}{l}\mathbf{4 4} \\
\mathbf{7 4}\end{array}$ & $\begin{array}{l}176 \\
179\end{array}$ \\
\hline \multirow[t]{2}{*}{ Total } & 202 & 361 & 563 & 610 & 80 & 690 & 237 & 118 & 355 \\
\hline & & $\begin{array}{l}\text { (df) }= \\
<0 .(\end{array}$ & & & $\begin{array}{l}\text { (df) }= \\
<0.0\end{array}$ & & & $\begin{array}{l}\text { (df) }= \\
<0.00\end{array}$ & \\
\hline
\end{tabular}

\section{Conclusions}

This survey was undertaken to guide those responsible for occupational health and safety in the veterinary service. The results suggest that the risk of zoonoses in this group of veterinary workers depends to a considerable extent on factors outside their immediate control. Their work must reflect the prevalence of disease in the animal population, and while wellrecognised hazards such as brucellosis are receding, others such as ornithosis, $Q$ fever, and rabies are of increasing importance. This survey strengthens the view that the laboratory workers shared the risks of those working in the animal pen and suggests that an association may exist between accidents, particularly with animals, and the risks of zoonotic infection. The high rate of injuries occurring when handling animals highlights the hazardous nature of some procedures and suggests the need for further study of the reasons for such accidents.

Our sincere thanks are expressed to the staff of the Ministry of Agriculture, Fisheries, and Food and to the Institute for Research in Animal Diseases, Compton, for their generous co-operation, interest, and support.

\section{References}

${ }^{1}$ Elliotson J. On the glanders in the human subject. Medico-Chirurgical Transactions 1930;16:171-218

2 Williams E. Brucellosis in veterinary surgeons in Wales. $f R$ Coll Physicians Lond 1976;10:351-62.

${ }^{3}$ Harrington JM, Shannon HS. Incidence of tuberculosis, hepatitis, brucellosis, and shigellosis in British medical laboratory workers. $\mathrm{Br}$ Med F 1976;i:759-62.

4 Sulkin SE. Laboratory acquired infections. Bacteriol Rev 1961 ;25:203-9.

5 Pike RM. Laboratory associated infections; incidence fatalities, causes and prevention. Ann Rev Microbiol 1979;33:41-66.

${ }^{6}$ Robinson RA, Metcalfe RV. Zoonotic infections in veterinarians. NZ Vet $\mathcal{F}$ 1976;24:201-10.

7 Schnurrenberger PR, Hanson LE, Martin RJ. Infections with Erysipelothrix, Leptospira and Chlamydia in Illinois veterinarians. Int $\mathcal{f}$ Zoonoses $1978 ; 5: 55-61$.

${ }^{8}$ Schnurrenberger PR, Martin RJ, Walker JF. Mortality in Illinois veterinarians. F Am Vet Med Assoc 1977;170:1071-5.

${ }^{9}$ Gentles JC, Holmes JG. Foot ringworm in coal miners. $\mathrm{Br} \mathcal{F}$ Ind Med 1957;14:22-9.

${ }^{10}$ Chatterjee A, Chattopadhyay D, Bhattacharya D, Dutta AK, Sen Gupta DN. Some epidemiological aspects of zoophilic dermatophytosis. Int $\mathcal{F}$ Zoonoses $1980 ; 7: 19-33$.

11 Communicable Disease Surveillance Centre. Anthrax in man and animals 1971-7. Communicable Disease Report 78/22. London: Public Health Laboratory Service. (Unpublished.)

12 Brodigan M, McDiarmid A, Mann PG, Skone JF. Brucellosis: an island epidemiological study. $\mathrm{Br}$ Med F 1961 ;ii:1393-6.

13 Galbraith NS, Forbes P, Mayon-White RT. Disappearing and declining diseases. Br Med F 1980;281:489-91.

14 Henderson RJ, Hill DM, Vickers AA, Edwards JMB, Tillet HE. Brucellosis and veterinary surgeons. $\mathrm{Br}$ Med $\mathcal{F} 1975 ; \mathrm{ii}: 656-9$.

15 Spink WW, Thompson HT. Human brucellosis caused by Brucella abortus, strain 19. FAMA 1953;153:1162-5.

${ }^{16}$ Coghlan JD. Leptospirosis in man, British Isles 1978. Br Med f 1979; ;ii: 872-3.

${ }^{17}$ Medical Research Council Tuberculosis and Chest Diseases Unit. National survey of tuberculous notifications in England and Wales 1978-9. Br Med f 1980;281:895-8.

18 Palmer SR, Andrews BE, Major R. A common-source outbreak of ornithosis in veterinary surgeons. Lancet. 1981 ;2:798-9.

(Accepted 24 November 1981)

$A$ woman in late middle age has smoked around 20 cigarettes a day for many years. On several occasions she has stopped smoking and subsequently developed acute ulceration of the mouth, gums, and tongue. Treatment was unsuccessful, but the ulcers healed when she restarted smoking. What might be the cause of these ulcers?

From the information given the patient is almost certainly suffering from bouts of minor aphthous ulceration. Aphthous ulceration is more common in non-smokers than smokers, and those with a tendency to aphthous ulceration who smoke often get attacks when they stop smoking. One can only speculate as to why this may occur. Ship et al ${ }^{1}$ showed the importance of stress and psychological factors in the aetiology of recurrent aphthous ulceration. Smoking may be a means of coping with stress, which, if discontinued, may result in the stress expressing itself as aphthous ulceration. Cheek and lip biting are also common in anxious individuals, and these are often precipitatory factors in aphthous ulceration. It is for the patient to decide which is the worse of the two evils, aphthous ulcers or smoking.-R B O SUTTON, senior lecturer in oral medicine, London.

'Ship II, Morris SW, Durocher RT, Burket LW. Recurrent aphthous ulceration and recurrent herpes labialis in a professional school student population. $\mathcal{f}$ Oral Surg 1960;13:1317-29. 